\title{
ITGAX wt Allele
}

National Cancer Institute

\section{Source}

National Cancer Institute. IT GAX wt Allele. NCI Thesaurus. Code C51170.

Human IT GAX wild-type allele is located in the vicinity of $16 \mathrm{p} 11.2$ and is approximately 28

$\mathrm{kb}$ in length. This allele, which encodes integ rin alpha-X protein, is involved in cellular adhesion and signal transduction. 